\title{
ストレスチェックの受検に関連する因子： 定期健康診断と同時期に実施することを中心とした検討
}

\author{
石丸 知宏 ${ }^{1,2}$, 服部 理裕 ${ }^{1,2}$, 永田 昌子 ${ }^{2}$, 桑原 恵介 ${ }^{3}$, 渡邊 聖二 ${ }^{1}$, 森 晃爾 ${ }^{2}$ \\ 1 西日本産業衛生会北九州産業衛生診療所健康管理部 \\ 2 産業医科大学産業生態科学研究所産業保健経営学 \\ 3 帝京大学大学院公衆衛生学研究科
}

\section{Factors Associated with Stress Check Attendance: Possible Effect of Timing of Annual Health Examination}

\author{
Tomohiro ISHIMARU ${ }^{1,2}$, Michihiro HATTORI ${ }^{1,2}$, Masako NAGATA², Keisuke KUWAHARA ${ }^{3}$, \\ Seiji WATANABE ${ }^{1}$ and Koji MORI ${ }^{2}$ \\ ${ }^{1}$ Department of Health Management, Nishinihon Occupational Health Service Center \\ ${ }^{2}$ Department of Occupational Health Practice and Management, Institute of Industrial Ecological Sciences, University of Occupational and \\ Environmental Health, Japan \\ ${ }^{3}$ Teikyo University Graduate School of Public Health
}

\begin{abstract}
Objectives: The stress check program has been part of annual employees' health screening since 2015. Employees are recommended, but not obliged, to undergo the stress check offered. This study was designed to examine the factors associated with stress check attendance.

Methods: A total of 31,156 Japanese employees who underwent an annual health examination and a stress check service at an Occupational Health Service Center in 2016 participated in this study. Data from the annual health examination and stress check service included stress check attendance, date of attendance (if implemented), gender, age, workplace industry, number of employees at the workplace, and tobacco and alcohol consumption. Data were analyzed using multiple logistic regression.

Results: The mean rate of stress check attendance was $\mathbf{9 0 . 8 \%}$. A higher rate of stress check attendance was associated with a lower duration from the annual health examination, age $\geq \mathbf{3 0}$ years, construction and transport industry, and 50-999 employees at the workplace. A lower rate of stress check attendance was associated with medical and welfare industry and $\geq 1,000$ employees at the workplace.

Conclusions: These findings provide insights into developing strategies for improving the rate of stress check attendance. In particular, stress check attendance may improve if the stress check service and annual health examination are conducted simultaneously.
\end{abstract}

Key words: health examination (健康診断), mental health (メンタルヘルス), occupational health service（労㗢衛生サービス), stress check（ストレスチェック）

受付 2017 年 9 月 20 日, 受理 2017 年 12 月 13 日

Reprint requests to: Tomohiro ISHIMARU

Department of Health Management, Nishinihon Occupational Health Service Center, 1-4-8 Higashida, Yahatahigashi-ku, Kitakyushu, Fukuoka 805-0071, Japan

FAX: +81(93)671-8140

E-mail: ishimaru@med.uoeh-u.ac.jp

\section{I.はじめに}


してより働きやすい職場作りに取り組むことを目的とし ている(2)。いずれの目的のためにも多くの労働者がス トレスチェックを受検することが重要である。川上らの 調査によると，ストレスチェックの受検率が $80 \%$ 以上 を超える事業所が全体の 4 分の 3 を占める一方で，20\% 未満の事業所が $8.9 \%$ 存在した (3)。

ストレスチェックに関する先行研究は, 高ストレスの 関連因子に関するものが多く, 受検率の関連因子に関す る研究は臣とんどなされていない(4-10)。労働者のス トレスチェック受検の阻害要因としては,「自身の心の 状態を回答することの敷居が高い」,「自身の健康に関心 がない, または問題ないと思っている」,「運用に問題が あり回答や提出に支障がある」,「既に精神疾患の治療を している」, など様々な可能性が考兄られる。事業者は 受検率を高めるような運用を考慮すべきであるが，効果 的な取り組みは明らかとなっていない。

過去の調査や先行研究から, 個人属性や組織属性, 実 施時期や手軽さが健康診断等の受診率に影響することが 指摘されている (11-16)。我々は, 定期健康診断がすでに 職場で広く普及していることに着眼し，ストレスチェッ クを定期健康診断と同時期に実施することが受検の心理 的阻害要因を軽減し, 受検率を向上させる可能性がある と仮説を立てた。従って, 本研究の目的はストレスチェッ クの受検に関連する因子, 特に定期健康診断と同時期に 実施することの効果, を評価することである。ストレス チェックの受検率を向上させることは, 労働者のメンタ ルヘルス不調の未然防止に寄与する可能性がある。

\section{II. 方 法}

\section{1. 研究デザイン}

横断研究

\section{2. 対象・調査方法}

2016 年 1 月から同年 12 月までに労衝衛生機関 A 社の ストレスチェックサービスと巡回による定期健康診断の 両方を利用した労働者を対象に，ストレスチェックサー ビスと定期健康診断結果のデータを用いた。A 社の当該 期間に打けるストレスチェックサービスの対象者は 78,691 人，巡回による定期健康診断の受診者は 122,036 人で，両方を利用した者は 31,470 人だった。定期健康 診断結果の問診票未記入者 $(n=7)$, ストレスチェック 制度はメンタルヘルス不調を未然に防止することを目的 としているため, 精神疾患の治療歴ありの者 $(n=307)$ を除外し，31,156 名の結果を解析した。精神疾患の治療 歴は, 定期健康診断時に診察医が問診で治療歴を確認し, 疾病及び関連保健問題の国際統計分類第 10 版（ICD-10） で精神抏よび行動の障害（第 5 章）に分類された疾患を 対象とした。

$\mathrm{A}$ 社のストレスチェックの運用を説明する。まず A 社より各事業所の担当者に自記式のストレスチェックの
調査票を送付し，各事業所の担当者から対象者に調査票 を配布した。調査票は職業性簡易ストレス調査票を用い たマークシート記入方式であり, その内容は心身の自覚 症状，心理的負担の原因，他の労働者による支援の 3 尺 度から成る 57 項目の質問で構成されている(2)。記入 後は，同時に送付した封筒に封入後，糊付けをして中が 見られないよらにした上で, 各事業所の担当者に提出し, 最終的に A 社が受領した。回答期間は事業所毎に異な るが，概ね半月を目安としている。

\section{3. 調査項目}

ストレスチェックの結果から，回答日，性別，年齢 （16-29 歳，30-39 歳，40-49 歳，50-59 歳，60 歳以上に 分類), 業種 (国勢調査の産業大分類 20 種から選択し, 対象者が 1,000 名未満の業種はその他に分類), 事業所 規模（従業員数 50 人未満，50-299人，300-999人，1,000 人以上に分類）を利用した。

定期健康診断の結果から，定期健康診断の受診日，喫 煙習慣 (喫煙, 過去喫煙, 非喫煙), 飲酒習慣（なし, 時々, 毎日）を抽出した。

ストレスチェックの調査票を未提出の場合は回答日の 情報が得られないことから，当該事業所の全提出者に㧤 ける回答日の中央值を各人のストレスチェックの受検日 とした。その上で, 定期健康診断の受診日との差を算出 した。調査票の回答期間の目安を半月としているため, 定期健康診断の受診日の前後 $0 \sim 15$ 日を同時期の実施, 前後 $16 \sim 30$ 日をやや同時期の実施，前後 31 日以上を 異なる時期の実施の 3 つに実施時期を分類した。

\section{4. 統計解析}

独立変数を実施時期, 性別, 年齢, 業種, 事業所規模, 喫煙, 飲酒とし，従属変数をストレスチェックの受検の 有無とした。最初に, 記述統計を行い, ストレスチェッ クの受検の有無別にそれぞれの因子の数（n）および割 合（\%）を算出した。さらに，対象者が勤務する事業所 の数（n）を業種別と事業所規模別に算出した。次に, カイ二乗検定にてストレスチェック受検の有無と関連す る因子を評価した。最後に，カイ二乗検定で有意差を認 めた独立変数を含む調整オッズ比（OR）と $95 \%$ 信頼区 間（CI）を多重ロジスティック回帰分析にて算出した。 両側 $\mathrm{p}$ 值が 0.05 未満を統計学的有意差ありと判定した。 統計ソフトとして, SPSS 17.0 (SPSS Inc., Chicago, IL, USA）を用いた。

\section{5. 倫理的配慮}

本研究は, 産業医科大学倫理委員会の承認を得て実施 した（受付番号 H29-57 平成 29 年 6 月 8 日)。

\section{III. 結果}

Table 1 に調査対象者の特徵を示した。対象者（31,156 
Table 1. Characteristics of employees who received both annual health examination and stress check service at an Occupational Health Service Center in 2016

\begin{tabular}{|c|c|c|c|c|c|c|}
\hline & \multicolumn{2}{|c|}{ Total } & \multicolumn{2}{|c|}{ Attendance of stress check } & \multicolumn{2}{|c|}{ Non-attendance of stress check } \\
\hline & $\begin{array}{l}\mathrm{n}=31,156 \\
(100.0 \%)\end{array}$ & $(\%)$ & $\begin{array}{c}\mathrm{n}=28,294 \\
(90.8 \%)\end{array}$ & $(\%)$ & $\begin{array}{c}\mathrm{n}=2,862 \\
(9.2 \%)\end{array}$ & $(\%)$ \\
\hline \multicolumn{7}{|c|}{ Duration from annual health examination (days) } \\
\hline $0-15$ & 14,689 & $(47.1)$ & 14,119 & $(49.9)$ & 570 & $(19.9)$ \\
\hline $16-30$ & 4,725 & $(15.2)$ & 4,488 & $(15.9)$ & 237 & $(8.3)$ \\
\hline 31 or more & 11,742 & $(37.7)$ & 9,687 & $(34.2)$ & 2,055 & $(71.8)$ \\
\hline \multicolumn{7}{|l|}{ Gender } \\
\hline Female & 11,775 & $(37.8)$ & 10,266 & $(36.3)$ & 1,509 & $(52.7)$ \\
\hline Male & 19,381 & $(62.2)$ & 18,028 & $(63.7)$ & 1,353 & $(47.3)$ \\
\hline \multicolumn{7}{|l|}{ Age (years) } \\
\hline $16-29$ & 5,509 & $(17.7)$ & 4,743 & $(16.8)$ & 766 & $(26.7)$ \\
\hline $30-39$ & 6,810 & (21.9) & 6,166 & $(21.8)$ & 644 & $(22.5)$ \\
\hline $40-49$ & 7,927 & $(25.4)$ & 7,330 & $(25.8)$ & 597 & (20.9) \\
\hline $50-59$ & 6,302 & $(20.2)$ & 5,821 & $(20.6)$ & 481 & $(16.8)$ \\
\hline 60 and over & 4,608 & $(14.8)$ & 4,234 & $(15.0)$ & 374 & $(13.1)$ \\
\hline \multicolumn{7}{|l|}{ Industry } \\
\hline Manufacturing & 9,713 & $(31.2)$ & 9,174 & $(32.4)$ & 539 & $(18.8)$ \\
\hline Government & 5,170 & $(16.6)$ & 5,004 & $(17.7)$ & 166 & $(5.8)$ \\
\hline Construction & 1,281 & (4.1) & 1,227 & $(4.3)$ & 54 & (1.9) \\
\hline Transport & 1,478 & $(4.7)$ & 1,436 & (5.1) & 42 & $(1.5)$ \\
\hline Whole sale and retail & 4,122 & (13.2) & 3,752 & (13.3) & 370 & (12.9) \\
\hline Medical and welfare & 5,432 & $(17.4)$ & 3,937 & (13.9) & 1,495 & $(52.1)$ \\
\hline Others & 3,960 & $(12.8)$ & 3,764 & (13.3) & 196 & $(6.8)$ \\
\hline \multicolumn{7}{|c|}{ Number of employees (persons) } \\
\hline $1-49$ & 2,021 & $(6.5)$ & 1,765 & $(6.2)$ & 256 & $(8.9)$ \\
\hline $50-299$ & 15,782 & $(50.6)$ & 14,593 & $(51.6)$ & 1,189 & $(41.6)$ \\
\hline 300-999 & 10,084 & $(32.4)$ & 9,580 & $(33.9)$ & 504 & $(17.6)$ \\
\hline 1,000 or more & 3,269 & $(10.5)$ & 2,356 & $(8.3)$ & 913 & (31.9) \\
\hline \multicolumn{7}{|l|}{ Smoking } \\
\hline Non smoking & 16,437 & $(52.7)$ & 14,706 & $(51.9)$ & 1,731 & $(60.5)$ \\
\hline Past smoking & 4,785 & $(15.4)$ & 4,430 & $(15.7)$ & 355 & $(12.4)$ \\
\hline Current smoking & 9,934 & $(31.9)$ & 9,158 & $(32.4)$ & 776 & $(27.1)$ \\
\hline \multicolumn{7}{|l|}{ Alcohol } \\
\hline Never & 14,267 & $(45.8)$ & 12,828 & $(45.3)$ & 1,439 & $(50.3)$ \\
\hline Occasionally & 10,085 & (32.4) & 9,198 & (32.5) & 887 & $(31.0)$ \\
\hline Regularly & 6,804 & (21.8) & 6,268 & $(22.2)$ & 536 & (18.7) \\
\hline
\end{tabular}

名）の平均年齢は 43.8 歳（標準偏差 13.2, 範囲 17-89), 男性が約 6 割だった。ストレスチェックの受検率は 90.8\% であった。対象者が勤務する事業所の総数は 341 で，事業所の規模が 50-299人で 199 事業所 (58.4\%), 業種が製造業で 100 事業所（29.3\%）とそれぞれ一番多 かった（Figs. 1,2）。

Table 2 にストレスチェックの受検に対するカイ二乗 検定执よび多重ロジスティック回帰分析の結果を示す。 カイ二乗検定では，ストレスチェックの実施時期，性別， 年齢, 業種, 従業員数, 契煙, 飲酒に打いて有意差を認 めた $(\mathrm{p}<0.001)$ 。これらの変数を独立変数として，多 重ロジスティック回帰分析を行った結果, ストレス チェックの実施時期が巡回による定期健康診断と近いほ どストレスチェックの受検率は有意に高かった。年齢で
は，16-29 歳の群と比較して，30-39 歳，40-49 歳，5059 歳, 60 歳以上の群で調整オッズ比が約 1.5 倍高かっ た $(\mathrm{p}<0.001)$ 。業種では，製造業と比較して，建設業 と運輸業・郵便業でストレスチェックの受検率が有意に 高く，医療・福祉では有意に低かった。事業所の規模で は，1-49人の群と比較して，300-999人，50-299人の 群でストレスチェックの受検率が有意に高く，1,000人 以上の群では有意に低かった。

\section{IV. 考察}

A 社のストレスチェックサービスと巡回による定期健 康診断の両方を利用した労働者を対象にストレスチェッ クの受検に関連する因子の評価を行った。A 社における 


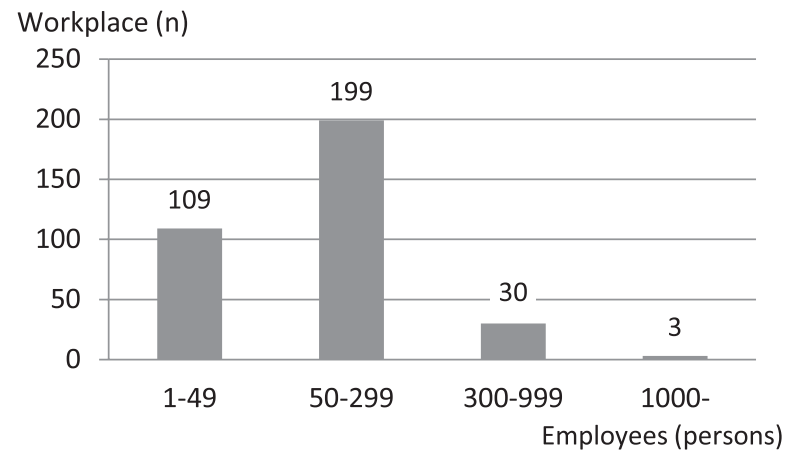

Fig. 1. Number of workplaces by scale of employment that conducted both annual health examination and stress check service at an Occupational Health Service Center in 2016.

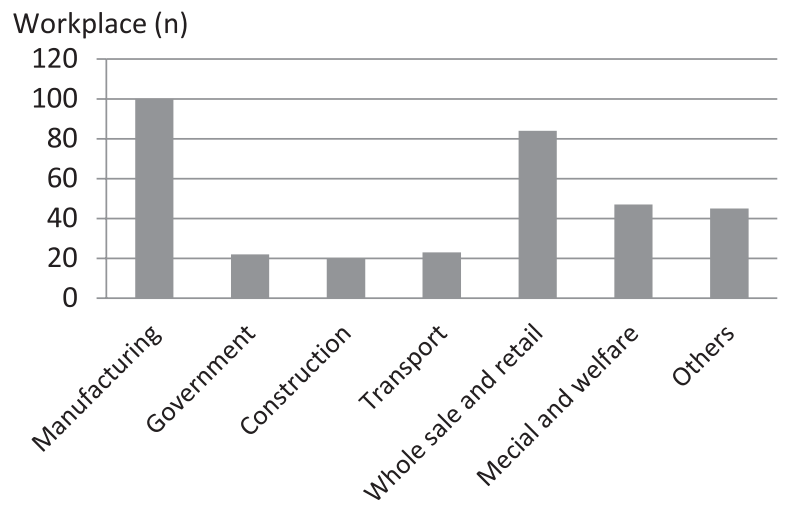

Fig. 2. Number of workplaces by type of business that conducted both annual health examination and stress check service at an Occupational Health Service Center in 2016.

Table 2. Factors associated with stress check attendance of 31,156 employees analyzed using Chi-square test and multiple logistic regression

\begin{tabular}{|c|c|c|c|c|c|c|}
\hline & \multicolumn{3}{|c|}{ Univariate } & \multicolumn{3}{|c|}{ Adjusted } \\
\hline & OR & $(95 \% \mathrm{CI})$ & $\mathrm{p}$ value & OR & $(95 \% \mathrm{CI})$ & $\mathrm{p}$ value \\
\hline \multicolumn{7}{|c|}{ Duration from annual health examination (days) } \\
\hline 31 or more & 1.00 & - & - & 1.00 & - & - \\
\hline $16-30$ & 4.02 & $(3.50-4.62)$ & $<0.001$ & 1.72 & $(1.47-2.00)$ & $<0.001$ \\
\hline $0-15$ & 5.26 & $(4.77-5.79)$ & $<0.001$ & 3.84 & $(3.46-4.27)$ & $<0.001$ \\
\hline \multicolumn{7}{|l|}{ Gender } \\
\hline Female & 1.00 & - & - & 1.00 & - & - \\
\hline Male & 1.96 & $(1.81-2.12)$ & $<0.001$ & 0.99 & $(0.89-1.10)$ & 0.810 \\
\hline \multicolumn{7}{|l|}{ Age (years) } \\
\hline $16-29$ & 1.00 & - & - & 1.00 & - & - \\
\hline $30-39$ & 1.55 & $(1.38-1.73)$ & $<0.001$ & 1.42 & $(1.25-1.62)$ & $<0.001$ \\
\hline $40-49$ & 1.98 & $(1.77-2.20)$ & $<0.001$ & 1.65 & $(1.44-1.88)$ & $<0.001$ \\
\hline $50-59$ & 1.95 & $(1.73-2.20)$ & $<0.001$ & 1.65 & $(1.44-1.90)$ & $<0.001$ \\
\hline 60 and over & 1.82 & $(1.60-2.08)$ & $<0.001$ & 1.41 & $(1.21-1.65)$ & $<0.001$ \\
\hline \multicolumn{7}{|l|}{ Industry } \\
\hline Manufacturing & 1.00 & - & - & 1.00 & - & - \\
\hline Government & 1.77 & $(1.48-2.12)$ & $<0.001$ & 1.07 & $(0.89-1.29)$ & 0.470 \\
\hline Construction & 1.34 & $(1.00-1.78)$ & 0.046 & 1.95 & $(1.45-2.61)$ & $<0.001$ \\
\hline Transport & 2.01 & $(1.46-2.77)$ & $<0.001$ & 2.73 & $(1.97-3.78)$ & $<0.001$ \\
\hline Whole sale and retail & 0.60 & $(0.52-0.69)$ & $<0.001$ & 1.00 & $(0.85-1.16)$ & 0.959 \\
\hline Medical and welfare & 0.16 & $(0.14-0.17)$ & $<0.001$ & 0.16 & $(0.14-0.18)$ & $<0.001$ \\
\hline Others & 1.13 & $(0.96-1.34)$ & 0.152 & 1.02 & $(0.86-1.22)$ & 0.820 \\
\hline \multicolumn{7}{|c|}{ Number of employees (persons) } \\
\hline $1-49$ & 1.00 & - & - & 1.00 & - & - \\
\hline $50-299$ & 1.78 & $(1.54-2.06)$ & $<0.001$ & 1.44 & $(1.26-1.77)$ & $<0.001$ \\
\hline $300-999$ & 2.75 & $(2.35-3.23)$ & $<0.001$ & 3.14 & $(2.60-3.78)$ & $<0.001$ \\
\hline 1,000 or more & 0.37 & $(0.32-0.44)$ & $<0.001$ & 0.52 & $(0.44-0.62)$ & $<0.001$ \\
\hline \multicolumn{7}{|l|}{ Smoking } \\
\hline Non smoking & 1.00 & - & - & 1.00 & - & - \\
\hline Past smoking & 1.47 & $(1.31-1.66)$ & $<0.001$ & 1.04 & $(0.91-1.20)$ & 0.560 \\
\hline Current smoking & 1.39 & $(1.27-1.52)$ & $<0.001$ & 0.92 & $(0.83-1.02)$ & 0.115 \\
\hline \multicolumn{7}{|l|}{ Alcohol } \\
\hline Never & 1.00 & - & - & 1.00 & - & - \\
\hline Occasionally & 1.16 & $(1.07-1.27)$ & $<0.001$ & 1.12 & $(1.01-1.24)$ & 0.028 \\
\hline Regularly & 1.31 & $(1.18-1.46)$ & $<0.001$ & 0.84 & $(0.75-0.95)$ & 0.007 \\
\hline
\end{tabular}

OR: Odds Ratio; 95\%CI: 95\% Confidence Interval (adjusted for duration from annual health examination, gender, age, industry, number of employees, smoking, and alcohol) 
ストレスチェックの受検率は $90.8 \%$ で，先行研究より 高い水準であった（17）。ストレスチェックの受検は実 施時期が巡回による定期健康診断と近いこと，30 歳以 上，建設業や運輸業・郵便業などの業種，事業所規模が 50-999人で有意に高かったが，医療・福祉，事業所規 模が 1,000 人以上では有意に低かった。

本研究は，ストレスチェックを巡回による定期健康診 断と同時期に実施することで受検率を向上させる可能性 を示唆している。がん検診や特定健康診査に関寸る先行 研究でも，実施時期が受診率に影響することが指摘され ている $(15,18)$ 。定期健康診断の実施率は $91.9 \%$ と高く, 就業時間内の実施が広く普及している (11)。定期健康 診断は受検の心理的阻害要因を軽減し, 様々な追加検査 を行ら良い機会だと言える（19）。巡回健診のスタッフ が質問紙の回収を協力することで，企業担当者の業務量 削減につながる可能がある。さらには，定期健康診断の 事後措置面談の時期に，医師による面接指導を実施する ことができるため，受検率だけでなく面談対象者のプラ イバシ一確保の観点からも好ましい面がある。

16-29歳の群と比較して, 他の年齢群でストレス チェックの受検率に対する調整オッズ比が約 1.5 倍高 かったが，これは若年労働者の受検率が低い可能性を示 唆している。健康診断に関する先行研究でも, 年齢が低 い注ど受診率が低下することが指摘されている（12, 13）。若年労働者は自身の健康への関心が低く，ストレ スチェックへの回答を面倒に感じていることが背景にあ ると推測される。そのため, ストレスチェックはメンタ ルヘルス不調の早期発見だけでなく，より働きやすい職 場作りのためにも必要であることを, 若年労働者を中心 に啓発する必要がある。

本研究では，製造業と比べて医療・福祉に抢けるスト レスチェックの受検率が有意に低かった。医療従事者は 一般的にメンタルヘルスを含めた自身の健康を安易に自 己診断し，他人による診断を忌避する傾向がある $(20$, 21）。例えば，医師のうち，13\%しか自身がメンタルヘ ルス不調の際に安心して受診できる医療機関がないと回 答している $(22)$ 。医療従事者への健康介入には他の職 種と異なり，特別なスキルが要求される (23)。今後の 研究に扣いて，医療・福祉に扣けるストレスチェックの 受検率を高める方策の検討を要する。

一方，ストレスチェックの受検率が高い業種として, 建設業や運輸業・郵便業が挙げられた。これらは労働災 害による死亡者数が多い，または事故により多くの犠牲 者が発生しらる業種であるため, 従前より安全文化の構 築や対策に力が入れられてきた (24)。例えば，鉄道運 転手に対しては, 定期健康診断の導入以前から安全に運 行するための医学適性検査が行われてきた (25)。高い 安全意識が受検率を高めている可能性があり, ストレス チェックのみならず，他の活動も含めた総合的な取り組 みが重要だと考えらえる。

本研究では, 事業所の規模が 1-49人の群と比較して,
50-999人の群ではストレスチェックの受検率が有意に 高く, 1,000 人以上の群では有意に低かった。通常，事 業所の規模が小さいほど安全衛生活動は不十分になりが ちであるため（26），定期健康診断の受診率が低くなる (11)。今回， 1,000 人以上の群でストレスチェックの受 検率が低かったが，その要因として，今回の調査に括け る 1,000 人以上の事業所の数が 3 つと少ないため，偶然 そのような結果になった可能性が考えられた。今後の研 究に㧧いて， 1,000 人以上の事業所の数を十分確保した 上で改めて評価する必要がある。

先行研究に扣いて, 契煙や過度の飲酒など不健康な生 活習慣を持つ者は一般的に健康意識が低く，ワクチンの 接種率やがん検診の受検率が低いと報告されている $(27$, 28)。本研究の単変量解析では, 先行研究とは異なり, 契煙や飲酒習慣のある者でストレスチェックの受検率が 有意に高かったが，性別や業種などを調整した多变量解 析では機会飲酒者のみで同様の結果を認めた。そのため, 回帰モデルに投入する独立变数を变更して再解析したと ころ，性別と医療・福祉の業種の投入で結果が大きく変 化して招り，性別や業種が交絡因子として働いたと考え られた。

本調査の強みとして，初めてストレスチェックの受検 に関連する因子を評価したこと，多様な業種からなる十 分な標本数が挙げられる。ただし, 本調査の限界として, 本調査は A 社の紙面で行らストレスチェックサービス と巡回による定期健康診断の両方を利用した労働者に招 けるストレスチェックの受検率を評価している。そのた め，ウェブで行らストレスチェックを利用していたり， 巡回による定期健康診断を受診していない労働者への一 般化はできない。次に，本調査は当該事業所の全提出者 における回答日の中央值を各人のストレスチェックの受 検日として扣り，実際の回答日とは異なる。また，本調 査は横断研究であり因果関係の検討には至っていない。

今回の調査はストレスチェックの受検率に関連する因 子の評価を行った。ストレスチェックを巡回による定期 健康診断の時期に実施することで受検率を高める可能性 がある。また，対象者の年齢，業種，事業所の規模によ り，ストレスチェックの受検率が異なっていた。こうし た特徵を踏まえた対策を行らことでストレスチェックの 受検率を向上させる可能性がある。

\section{謝辞}

本研究の実施にあたって，データ収集に御協力いただ いた西日本産業衛生会の大庭大輝様，川副愛子様，貞永 康名様に心から感謝いたします。

利益相反 : 著者の森晃爾は西日本産業衛生会の顧問て ある。 


\section{文献}

( 1 ) http://www.mhlw.go.jp/bunya/roudoukijun/anzeneisei12/ pdf/150507-1.pdf (2017.7.1)

(2) Kawakami N, Tsutsumi A. The Stress Check Program: a new national policy for monitoring and screening psychosocial stress in the workplace in Japan. J Occup Health 2016;58:1-6.

(3) https://mental.m.u-tokyo.ac.jp/jstress/H27ストレスチェッ ク班報告書 .pdf (2017.7.1)

(4) Haruyama Y, Matsuzuki H, Tomita S, Muto T, Haratani T, Muto S, et al. Burn and cut injuries related to job stress among kitchen workers in Japan. Ind Health 2014;52:113120.

( 5 ) Kawada T. Relationship between components of the metabolic syndrome and job strain using a brief job stress questionnaire (BJSQ). Int Arch Occup Environ Health 2013;86: 725-726.

( 6 ) Kawada T, Otsuka T. Relationship between job stress, occupational position and job satisfaction using a brief job stress questionnaire (BJSQ). Work 2011;40:393-399.

( 7 ) Matsuzaki K, Uemura H, Yasui T. Associations of menopausal symptoms with job-related stress factors in nurses in Japan. Maturitas 2014;79:77-85.

( 8 ) Wada K, Sairenchi T, Haruyama Y, Taneichi H, Ishikawa Y, Muto T. Relationship between the onset of depression and stress response measured by the Brief Job Stress Questionnaire among Japanese employees: a cohort study. PLoS One 2013;8:e56319.

( 9 ) Yada H, Abe H, Lu X, Wakizaki Y, Omori H, Matsuo H, et al. Job-related stress in psychiatric nurses in Japan caring for elderly patients with dementia. Environ Health Prev Med 2014;19:436-443.

(10) Yoshino K, Suzuki S, Ishizuka Y, Takayanagi A, Sugihara N, Kamijyo H. Relationship between job stress and subjective oral health symptoms in male financial workers in Japan. Ind Health 2017;55:119-126.

(11) http://www.mhlw.go.jp/toukei/youran/roudou-nenpou2012/ 05.html (2017.7.1)

(12) Bjerregaard AL, Maindal HT, Bruun NH, Sandbaek A. Patterns of attendance to health checks in a municipality setting: the Danish 'Check Your Health Preventive Program'. Prev Med Rep 2017;5:175-182.

(13) Hoebel J, Starker A, Jordan S, Richter M, Lampert T. Determinants of health check attendance in adults: findings from the cross-sectional German Health Update (GEDA) study. BMC Public Health 2014;14:913.

（14）舟橋博子, 西田友子, 岡村雪子, 榊原久孝. 中年期に 打䊗特定健康診査未受診者の特性. 日本公衆衛生雑
誌 2013;60:119-127.

（15）菅原彰一，松田 徹. 働く世代のがん検診未受診者対 策の有効性. 日本公衆衛生雑誌 2013;60:396-402.

(16) Dryden R, Williams B, McCowan C, Themessl-Huber M. What do we know about who does and does not attend general health checks? Findings from a narrative scoping review. BMC Public Health 2012;12:723.

(17) http://www.mhlw.go.jp/file/05-Shingikai-11201000Roudoukijunkyoku-Soumuka/0000061407.pdf (2017.7.1)

（18）築島恵理, 高橋恭子, 矢野公一, 森 満. 所得状況に よる特定健康診査の受診行動と関連する因子の検討 所得の指標として市民税課税層と非課税層の相違に 着目して。 日本公衆衛生雑誌 2012;59:810-821.

(19) Ishimaru T, Wada K, Smith DR. HIV testing and attitudes among the working-age population of Japan: annual health checkups may offer an effective way forwards. Ind Health 2016;54:116-122.

(20) Balon R. Psychiatrist attitudes toward self-treatment of their own depression. Psychother Psychosom 2007;76:306310 .

(21) Steffen MW, Hagen PT, Benkhadra K, Molella RG, Newcomb RD, Murad MH. A survey of physicians' perceptions of their health care needs. Occup Med (Lond) 2015; 65:49-53.

(22) Frank E, Segura C. Health practices of Canadian physicians. Can Fam Physician 2009;55:810-811 e817.

(23) Tyssen R. Health problems and the use of health services among physicians: a review article with particular emphasis on Norwegian studies. Ind Health 2007;45:599-610.

(24) Gao R, Chan AP, Utama WP, Zahoor H. Multilevel Safety Climate and Safety Performance in the Construction Industry: Development and Validation of a Top-Down Mechanism. Int J Environ Res Public Health 2016;13.

（25）木村か扣る，清治邦章，五十嵐孝之，麦倉正敏，黒羽 正男, 佐藤 研. Brugada 型心電図を示す社員への対 応一検診におけるスクリーニング法確立に向けて一. 産業衛生学雑誌 2005;47:67-69.

（26）池上和範, 野澤弘樹, 道井聡史, 菅野良介, 安藤 肇, 長谷川将之ら，産業医活動記録票を用いた嘱託産業医 活動の実態調査. 産業衛生学雑誌 2016;58:251-259.

(27) Vander Weg MW, Howren MB, Cai X. Use of routine clinical preventive services among daily smokers, non-daily smokers, former smokers, and never-smokers. Nicotine Tob Res 2012;14:123-130.

(28) Sicsic J, Franc C. Obstacles to the uptake of breast, cervical, and colorectal cancer screenings: what remains to be achieved by French national programmes? BMC Health Serv Res 2014;14:465. 